\title{
O DESRESPEITO AO PRINCÍPIO DA VALORIZAÇÃO DO TRABALHO HUMANO POR MEIO DA CONTRATAÇÃO TEMPORÁRIA DE SERVIDORES PÚBLICOS
}

\author{
Gustavo Alexandre Magalhães*
}

1. Introdução. 2. Contratação sem realização prévia de Concurso Público. 3. Contratação Mediante Realização de Concurso Público. 3.1. Nulidade das Contrataçōes em virtude do Desvio de Finalidade. 3.2. Efetivação dos Servidores Aprovados em Concurso mas Contratados Temporariamente. 4. Da Supressão do Direito às Férias e $13^{\circ}$ Salário. 5. Conclusões. 6. Referências Bibliográficas.

\section{Introdução}

A Constituição Federal de 1988 determinou em seu art. 37, II, que a admissão de pessoal para ocupar cargos ou empregos públicos fica condicionada à realização prévia de concurso público, atendendo-se ao princípio da isonomia (iguais chances de acesso a todos) e da eficiência (seleção dos melhores candidatos).

Excepcionalmente, a Carta de 1988 previu a possibilidade de contratação de agentes temporários para satisfazer a necessidades de excepcional interesse público, conforme estabelece o art. 37, IX.

Aproveitando-se da medida excepcional prevista pelo Constituinte, a Administração vem utilizando com frequiência da contratação por tempo determinado no intuito de admitir servidores para atender às aludidas "necessidades transitórias".

Ocorre que muitas vezes essas admissões demonstram-se fraudulentas, pois, como os contratos são prorrogados inúmeras vezes, não há transitoriedade do vínculo e nem excepcional interesse público. Não estando presentes os requisitos para a contratação excepcional, os agentes deveriam ser previamente aprovados em concurso público, conforme determina o art. 37 , II, da $\mathrm{CF} / 88$.

* Mestre em Direito Administrativo pela UFMG, Professor da Associação Nacional dos Magistrados Estaduais - ANAMAGES, Advogado em Belo Horizonte - MG.

\begin{tabular}{lll}
\hline R. Dir. Adm., & Rio de Janeiro, 239: 111-118, & Jan./Mar. 2005 \\
\hline
\end{tabular}


Outra prática também comum consiste na contratação temporária dos candidatos aprovados em concurso público para cargo de provimento efetivo. Em vez de serem nomeados em caráter permanente, são admitidos por tempo determinado, por meio de acordos de curta duração. Observe-se, entretanto, que esses acordos são prorrogados por vezes seguidas, deixando claro que a necessidade nada tem de temporária ou transitória.

Por fim, é imperioso atentar para os contratos celebrados especificamente na área da educação, para vigorar entre fevereiro e dezembro. Invocando a transitoriedade do vínculo, a Administração nega aos referidos trabalhadores o direito a férias e décimo terceiro salário.

Como se vê. o instituto da contratação por tempo determinado, para atender a necessidades de excepcional interesse público, vem sendo utilizado pelo Poder Público como instrumento de fraudar a exigência constitucional de realização prévia de concurso público, sendo utilizado ainda em total contrariedade ao princípio da valorização do trabalho humano.

\section{Contratação sem realização prévia de Concurso Público}

Nos casos em que a contratação de servidores públicos temporários é realizada sem a prévia realização de concurso, mas de forma reiterada e por longos períodos. a conduta das autoridades públicas contraria o disposto no art. 37, II. da Constituição Federal.

Em virtude das várias prorrogações contratuais, fica evidente a inexistência de excepcional interesse público, não sendo aplicável, pois, o art. 37, IX da Carta de 1988. Deveria ser aplicada a regra geral, que impõe a realização de concurso público de provas ou de provas e títulos e, em seguida, a nomeação para cargo de provimento efetivo ou contratação para ocupar emprego público.

Entretanto. a admissão de pessoal sem a realização de processo seletivo prévio consiste em prática corrente, por meio da qual os trabalhadores são escolhidos livremente pela autoridade no intuito de obter vantagens pessoais, normalmente de cunho político. É patente a nulidade do vínculo, devendo-se interromper imediatamente a prestação de serviços a título precário, conforme determina o art. $37, \S 2^{\circ}$, da Constituição.

Em lugar dos servidores de fato, deve-se proceder à nomeação do pessoal devidamente concursado para os respectivos cargos ou empregos de provimento efetivo. Deve-se observar que embora seja nulo o vínculo, são devidas aos prestadores de serviço todas as verbas de natureza trabalhista, em atendimento ao princípio da moralidade administrativa e da valorização do trabalho. ${ }^{1}$

1 Entendimento diverso foi consagrado pelo Enunciado 363 do Tribunal Superior do Trabalho, o qual determina que, em caso de nulidade no vínculo, são devidos aos trabalhadores apenas os salários e os valores referentes aos depósitos do FGTS.

Ocorre que, ao remunerar os servidores de fato de boa-fé apenas com salários e FGTS, o TST acaba punindo a parte mais fraca da relação Estado-servidor. Os interesses da pessoa jurídica de 


\section{Contratação Mediante Realização de Concurso Público}

\subsection{Nulidade das Contratações em virtude do Desvio de Finalidade}

Alguns servidores públicos encontram-se em situação ainda mais delicada: são aprovados em concurso público para provimento efetivo, mas em vez de serem nomeados, continuam sendo contratados "temporariamente", a título precário.

Nestes casos, é flagrante o desvio de finalidade na conduta da autoridade pública que, reiteradamente, prorroga os contratos dos trabalhadores. Apesar de contar com um rol de candidatos aprovados em concurso público, não procede à nomeação ou à contratação efetiva. Em vez de concretizar os princípios da isonomia e eficiência por meio da nomeação dos melhores candidatos, escolhidos por regular processo de seleção, a Administração continua admitindo pessoal em caráter provisório, na pretensão de suprimir o direito à estabilidade no serviço público.

E não há que se alegar simplesmente que a nomeação consiste em ato discricionário do administrador, haja vista que, ao prorrogar "contratos temporários", evidencia a necessidade da prestação de serviços. A autoridade competente para a nomeação, que perpetua os vínculos precários, deve ser penalizada em decorrência do desvio de poder.

Observe-se que a celebração e prorrogação de contratos por tempo determinado até que prescreva o prazo de validade do concurso poderia ser utilizada, por exemplo, para que a autoridade competente não nomeasse qualquer servidor em caráter efetivo até que seus amigos ou aliados políticos fossem aprovados no concurso público.

Deve o aplicador do direito impedir que tais agressões ao ordenamento jurídico se perpetuem, visto que constituem ofensas gritantes ao princípio da isonomia, da impessoalidade e da moralidade administrativa.

Muito menos permite a Constituição que os trabalhadores sejam privados dos direitos decorrentes do vínculo permanente com o Estado, ficando à mercê da vontade de algumas autoridades públicas. Cabe ao Ministério Público apurar eventuais ilícitos criminais e atos de improbidade administrativa, visando a coibir condutas nocivas ao interesse público e à proteção do trabalho humano.

direito público devem estar em consonância com os demais princípios constitucionais, como o da valorização do trabalho humano e da dignidade da pessoa humana.

Além disso, deve-se atentar para o fato de que o argumento utilizado para deferir o pagamento dos salários e FGTS é evitar o enriquecimento ilícito da Administração. No entanto, o ordenamento jurídico-constitucional previu que qualquer prestação de serviços em caráter subordinado só será efetivamente compensada pelo pagamento de todos os direitos previstos no art. $7^{\circ}$ da Constituição. $O$ pagamento de qualquer montante que seja inferior ao que foi estabelecido pela Constituição continua sendo insuficiente para descaracterizar enriquecimento ilícito do Estado.

A pessoa jurídica de direito público contrata sem concurso, fere a Constituição, mas acaba sendo premiada com menor despesa com pagamento de pessoal. Está patente a imoralidade administrativa, vedada pelo art. 37, caput, da Constituição de 1988. 


\subsection{Efetivação dos Servidores Aprovados em Concurso mas Contratados}

\section{Temporariamente}

Se por um lado é patente o desvio de finalidade da Administração, por outro há que se acolher com reservas as alegações dos agentes temporários no sentido de terem direito à efetivação no serviço público. Argumentam que em face da aprovação em concurso público, o princípio da isonomia está atendido, e como trabalharam por longo período, está descaracterizada a transitoriedade do vínculo (art. 451 da CLT). Os tribunais registram casos de pedidos de reconhecimento de estabilidade no serviço público, quando os contratos são prorrogados por períodos que ultrapassam o estágio probatório ( 3 anos) exigido pelo art. 41 da Constituição Federal.

Primeiramente, cumpre observar que a estabilidade no serviço público, prevista pelo art. 41, é privativa dos servidores estatutários, ocupantes de cargo em provimento efetivo ${ }^{2}$. Lembre-se que os empregados públicos, embora não tenham a prerrogativa da estabilidade, são protegidos pelos princípios constitucionais da Administração Pública, sendo assegurado o direito ao devido processo legal, além de observância obrigatória ao princípio da finalidade e motivação. Portanto, como os empregados públicos não podem ser exonerados ou demitidos senão por processo administrativo, a diferença entre o servidor estável (estatutário) e o não estável (empregado público) reside apenas no direito à disponibilidade remunerada no caso de extinção ou declaração de desnecessidade do cargo ou emprego, que é exclusiva dos servidores estatutários ${ }^{3}$.

Por outro lado, quanto ao direito à declaração de efetividade do vínculo, a questão se mostra mais complexa. Ainda que reconhecida a invalidade das contratações temporárias, não há que se falar, automaticamente, em direito subjetivo à efetivação dos trabalhadores no serviço público.

Há que se perquirir, primeiramente, se existem cargos ou empregos públicos previamente criados, os quais consistem em condição sine qua non para a nomeação de servidores em caráter definitivo. Não há como efetivar um agente no serviço

2 Conferir estabilidade ao empregado público é negar ao Congresso Nacional o poder de emendar a Constituição. A E.C. $19 / 98$ alterou a redação do art. 41 da Constituição, de modo que a antiga estabilidade do "servidor público" foi substituída pela estabilidade do servidor "ocupante de cargo em provimento efetivo". Portanto, depois da alteração constitucional, a estabilidade é privativa do servidor estatutário, já que o empregado público não ocupa cargo, mas emprego público. Neste sentido, o seguinte julgado do TST: RR 611373, DJ 11.06.2004. Registre-se, contudo, que prevalece ainda no Tribunal Superior do Trabalho o entendimento pela existência de estabilidade também para o empregado público, conforme pacificado pela Orientação Jurisprudencial $n^{\circ} 265$ da Seção de Dissídios Individuais.

3 Vale transcrever as lições de Celso Antônio Bandeira de Mello, ilustrando o que entende a doutrina por estabilidade no serviço público: “Estabilidade — é o direito de não ser demitido do serviço público, salvo se incidir em falta funcional grave, apurada em processo judicial ou processo administrativo em que the seja assegurada ampla defesa ou em consequência de avaliação periódica de desempenho. igualmente assegurada ampla defesa" (Curso de direito administrativo. 15. ed. São Paulo: Malheiros, 2003, p. 277). 
público se não existir um lugar, criado por lei formal, com suas respectivas atribuições e remuneração.

Logo, caso não exista o cargo ou emprego, é vedada a nomeação ou contratação definitiva, sob pena de ofensa ao art. 37 , II, bem como ao art. $61, \S 1^{\circ}$, II, 'a', da Constituição de 1988.

Existindo cargos ou empregos, com suas respectivas atribuições e remuneração, a efetivação no serviço público dos concursados dependeria apenas de ato administrativo da autoridade competente, sendo desnecessária qualquer intervenção por parte do Poder Legislativo. Deve-se observar, no entanto, que é antiga no âmbito do direito administrativo a discussão sobre a possibilidade de o Poder Judiciário intervir no ato administrativo discricionário, em virtude do princípio da separação dos poderes.

Prevalece na Jurisprudência o entendimento do Supremo Tribunal Federal segundo o qual candidatos aprovados em concurso público têm mera expectativa de direito à nomeação, não podendo se falar em direito adquirido ${ }^{4}$.

Por outro lado, o próprio STF consagrou entendimento no sentido de haver direito adquirido à nomeação quando a ordem de classificação é desrespeitada pela Administração, nos termos da Súmula 15: "Dentro do prazo de validade do concurso, o candidato aprovado tem o direito a nomeação, quando o cargo for preenchido sem observância da classificação".

A Súmula 15 do STF, ratificada com o advento da Constituição de 1988 pelo disposto no art. 37 , IV ${ }^{5}$, visa a impedir a atuação da Administração com desvio de finalidade, visto que, comprovada a necessidade do serviço pela nomeação de outro candidato, não há mais que se falar em discricionariedade quanto à nomeação ou não de candidatos aprovados. Assim, se foi alegada a necessidade do serviço público para nomear candidato aprovado em colocação inferior à de outro, o concorrente preterido adquire direito subjetivo à sua nomeação. Caso contrário, estar-se-á permitindo que a autoridade aja de uma forma quando o candidato fizer parte de seu grupo político ou pessoal, e de outra forma quando o candidato não fizer parte de tal círculo.

O mesmo raciocínio adotado na Súmula 15 deve ser empregado ao analisar a situação de servidores temporários, os quais são contratados a título precário, apesar de terem sido aprovados em concurso público de provas e títulos. Constatada a necessidade permanente ${ }^{6}$, via de regra por meio de sucessivas prorrogações contra-

4 AI 373054/SP, DJ 03.09.2002; RE 229450/RJ, DJ 30.08.2001; RMS 23.788/DF, DJ 16.11.2001.

5 “Art. 37 - (omissis)

IV - Durante o prazo improrrogável previsto no edital de convocação, aquele aprovado em concurso público de provas ou de provas e títulos será convocado com prioridade sobre novos concursados para assumir cargo ou emprego, na carreira".

6 De fato, pode ocorrer que candidatos aprovados possam ser contratados temporariamente, a título precário, quando configurado excepcional interesse público. Embora exista necessidade imediata, às vezes não é possivvel aferir, de plano, quantos servidores serão necessários em caráter definitivo. Mas, ultrapassado o "período de turbulência", ou seja, constatada a permanência da necessidade (normalmente por meio de sucessivas prorrogações contratuais), a nomeação em caráter efetivo se impõe. 
tuais, os candidatos adquirem direito à nomeação. Caso contrário será abençoada conduta eivada de desvio de poder, pois o Poder Público contrata "temporariamente" trabalhadores por dois, três, às vezes mais de cinco anos, e alega não haver necessidade permanente que demande a efetivação do vínculo? ${ }^{7}$.

Portanto, se o Estado contrata servidores devidamente aprovados em concurso público, para trabalhar a título precário, deve ser reconhecida a efetividade do vínculo se ficar comprovada que a necessidade é permanente. Só não será possível efetivar o servidor se não houver cargo ou emprego previamente criado por lei.

\section{Da Supressão do Direito às Férias e $13^{\circ}$ Salário}

Outra prática administrativa que deve ser rigorosamente combatida pelo Poder Judiciário consiste na celebração de contratos por tempo determinado, com os servidores da área de educação, apenas no período compreendido entre fevereiro e dezembro.

Além de negar o direito de gozo de férias e de recebimento do décimo terceiro salário, o Poder Público se vale de tal prática no intuito de demonstrar a " necessidade transitória" da prestação de serviços. Assim, durante anos a fio, contrata as mesmas pessoas para trabalhar por dez ou onze meses, como se fossem contratos autônomos e independentes.

Nestes casos, independentemente de se reconhecer o direito à efetivação dos trabalhadores concursados no serviço público, deve-se condenar o Estado ao pagamento das verbas que lhe seriam devidas se o contrato fosse celebrado por tempo indeterminado ${ }^{8}$.

Se os contratos foram anulados, com base no art. $37, \S 2^{\circ}$, da Constituição, não há que se falar em vínculo indeterminado (art. 451 e 452 da CLT), pois, na verdade,

7 Em defesa do direito de nomeação dos candidatos aprovados, vale transcrever trecho do voto do Ministro Marco Aurélio Mello, do STF, nos autos do RMS 22.063-9/RJ: "Entendimento diverso é passivel de conduzir a verdadeiras manobras, visando ao esgotamento do prazo de validade do concurso para que outros candidatos concorram às vagas. A atuação da Administração Pública está jungida à legalidade e à impessoalidade. Aberto concurso público para o preenchimento de um certo número de vagas, descabe, aprovados os candidatos, dizer que as nomeações ficam sujeitas a critérios simplesmente discricionários". O Ministro Marco Aurélio foi vencido ao sustentar a inexistência de discricionariedade da Administração quando existem cargos vagos. Os Ministros Néri da Silveira e Maurício Corrêa entenderam que não existe obrigatoriedade de preencher os cargos e empregos públicos vagos, cf. STF. ROMS 22.063-9/RJ, DJ 07.12.1995. in www.stf.gov.br.

Contudo, vale salientar que, no caso de contratação seguida de inúmeras prorrogações do vínculo, está patente o desvio de finalidade, não sendo questão de simples preenchimento de cargos vagos. Ainda que se adote como premissa o entendimento consagrado pela jurisprudência, deve-se reconhecer o direito à efetivação dos candidatos aprovados quando a própria Administração evidencia a necessidade da prestação dos serviços.

8 Neste sentido, o Tribunal Regional da $15^{\text {a }}$ Região determinou a aplicação dos artigos 451 e 452 da CLT, reconhecendo a indeterminação do vínculo e, consequientemente, condenando o Município de Campinas ao pagamento de férias e $13^{\circ}$ salário, cf. RO 28.631/1997, in www.trtl5.gov.br. 
não existe qualquer vínculo regular. Mas no que concerne às verbas trabalhistas, deve o Judiciário reconhecer o prolongamento do vínculo, considerando o direito dos trabalhadores de receberem toda a remuneração devida em virtude da prestação de serviços. Portanto, são devidas as parcelas referentes às férias e ao décimo terceiro salário. Não é admissível que o Poder Judiciário seja cúmplice da Administração Pública no sentido de obstar, escancaradamente, o direito dos servidores temporários de receber as parcelas garantidas pela Constituição da República, como instrumento de efetivação do princípio da valorização do trabalho humano.

Em se tratando de candidatos aprovados em concurso público para provimento efetivo, mas que continuam sendo contratados por tempo determinado por várias vezes, a questão é menos complexa. Após o reconhecimento de sua condição de efetivo, o direito de recebimento das férias e décimo terceiro salário é automático, pois integra o rol de direitos do servidor estatutário ou celetista, conforme o regime jurídico local.

\section{Conclusões}

Nos casos em que o Poder Público contrata servidores sem a realização de concurso, mas prorroga por várias vezes o vínculo, não há que se falar em excepcional interesse público. Deve-se anular a contratação, punindo-se a autoridade responsável nos termos do art. $37, \S 2^{\circ}$, da CF/88.

Por outro lado, nos casos em que a Administração realiza concurso para provimento efetivo, mas em vez de nomear, contrata temporariamente e de forma reiterada os candidatos aprovados, está evidenciado o desvio de finalidade. Havendo cargos ou empregos criados por lei, deve ser reconhecida a efetividade dos mencionados agentes públicos.

Por fim, nas hipóteses de contratação temporária de pessoal de fevereiro a dezembro (ou novembro), por anos seguidos, sem que lhes seja concedido o direito a férias e décimo terceiro salário, deve o Poder Judiciário condenar o Estado a pagar todos os direitos decorrentes da prestação de trabalho em caráter subordinado, remunerado e eventual, visando a concretizar o princípio da valorização do trabalho humano. Os servidores da área de educação, que já não recebem a remuneração que merecem, têm direito de, pelo menos, ver efetivado aquilo que o Direito ainda lhes assegura.

\section{Referências Bibliográficas}

ARAÚJO, Florivaldo Dutra de. Conflitos coletivos e negociação coletiva na função pública, 1998. 462f. Tese (Doutorado em Direito Administrativo) - Faculdade de Direito, Universidade Federal de Minas Gerais, Belo Horizonte.

DI PIETRO, Maria Sylvia Zanella. Direito administrativo, 10. ed. São Paulo: Atlas, 1999 
FIGUEIREDO. Guilherme José Purvim de. O Estado no direito do trabalho. São Paulo: LTR, 1996.

GASPARINI. Diógenes. Direito administrativo, $6^{a}$ ed. São Paulo: Saraiva, 2001

MAIOR, Jorge Luiz Souto. $O$ direito do trabalho como instrumento de justiça social. São Paulo: LTR, 2000.

MEDAUAR, Odete. Direito administrativo moderno, $5^{\text {a }}$ ed. São Paulo: Revista dos Tribunais, 2001.

MELlo, Celso Antônio Bandeira de. Curso de direito administrativo. 11. ed. São Paulo: Malheiros, 1999.

MELLO, Oswaldo Aranha. Princípios gerais de direito administrativo. Rio de Janeiro: Forense, 1974, v. II. 